Editorial

\title{
"THE BRAZILIAN MEETINGS ON ORGANIC SYNTHESIS (BMOS)" UMA RETROSPECTIVA
}

A síntese orgânica no Brasil teve um início bastante modesto e não existia como tal na primeira metade do século passado. Foi na Universidade de São Paulo, na década de 50, que se iniciaram os trabalhos na área pelos profs. Marcelo de Moura Campos e Nicola Petragnani. Nessa época esses professores realizaram trabalhos pioneiros na área de química orgânica de compostos de selênio e telúrio, considerados naquela época uma curiosidade química, pois nenhuma aplicação prática era conhecida para os mesmos. Isso pela simples razão de que nada se sabia sobre eles!

Atualmente a química desses dois elementos vem se mantendo na fronteira do desenvolvimento da química orgânica sintética e várias reações descobertas naquela época no Instituto de Química da Universidade de São Paulo são hoje clássicas em química orgânica, constando de qualquer compêndio de química orgânica sintética. Exemplo disso é a reação de selenociclização de substratos insaturados (M. Moura Campos, N. Petragnani, Chem.Ber., 1960, 93, 317). Infelizmente, o crédito a essa descoberta pela comunidade internacional não é dado aos cientistas brasileiros.

No início da década de 70, com a instalação de grandes indústrias químicas no Brasil, fez-se necessária a formação de profissionais com visão moderna da Química. Na área da química orgânica sintética foi no laboratório do prof. Marcelo de Moura Campos que o CNPq buscou auxilio, ao estabelecer com a National Academy of Sciences (NAS) dos Estados Unidos, sob coordenação do prof. Carl Djerassi, um convênio que trouxe ao Brasil grandes pesquisadores americanos da época, entre eles H. Taube, W. S. Johnson, R. E. Ireland e J. Marshall, bem como jovens doutores e ex-estudantes desses cientistas para implantar novas linhas de pesquisa. O convênio na área de Síntese Orgânica, coordenado inicialmente pelo prof. Marcelo de Moura Campos e após sua aposentadoria pelo prof. Nicola Petragnani, teve êxito e podemos afirmar que foi o mais bem sucedido entre os vários convênios firmados na época entre o $\mathrm{CNPq}$ e a NAS, tendo formado um número considerável de mestres e doutores entre os quais aqueles que deram o impulso inicial para a criação dos "Brazilian Meetings on Organic Synthesis" (BMOS).

Mais ou menos na mesma época a Universidade de Brasília (UnB) e a Universidade Estadual de Campinas (Unicamp) contrataram químicos orgânicos brasileiros e estrangeiros formados nos Estados Unidos. Na década de 80, a Unicamp continuou a investir na área e na Universidade Federal do Rio de Janeiro e na Universidade Federal de
Minas Gerais químicos de produtos naturais passaram a se dedicar à síntese orgânica. No campus da Universidade de São Paulo em Ribeirão Preto e da Universidade Federal de São Carlos, no final da década de 70 e início da década de 80 , formaram-se grupos com doutores provenientes do laboratório de síntese orgânica do Instituto de Química da Universidade de São Paulo.

A partir da segunda metade da década de 80 todos os laboratórios acima mencionados passaram a formar pesquisadores na área de síntese orgânica, os quais estão exercendo atividades em empresas e Universidades de várias partes do Brasil.

A primeira tentativa de reunir os químicos orgânicos sintéticos brasileiros foi feita na Universidade de Brasília, em 1982, por iniciativa do prof. Peter Bakuzis, quando cerca de 15 químicos orgânicos se reuniram para discutir suas linhas de pesquisa.

Em 1986, um de nós (JVC) organizou um encontro informal no Instituto de Química da Universidade de São Paulo que reuniu cerca de 100 participantes, entre pesquisadores experientes e outros em início de carreira, estudantes de pós-graduação e graduação, todos tendo como tema de suas pesquisas a síntese orgânica. Nesse encontro foram lançadas as bases de um encontro periódico da comunidade dos químicos orgânicos sintéticos no Brasil, ficando estabelecido que o encontro seguinte seria realizado em Porto Alegre, sob a coordenação do prof. Valter Stefani e com a de um nós (JVC).

Efetivamente esse encontro ocorreu com grande sucesso em 1987, reunindo cerca de 200 participantes. Em Porto Alegre, ficou estabelecido que o encontro seguinte seria realizado em 1988 na cidade de São Carlos, SP tendo o prof. José Tércio B. Ferreira como secretário geral.

Esse encontro mudou o rumo dos encontros de síntese no Brasil, tendo divulgação internacional e contando com a participação de 9 cientistas estrangeiros do mais alto gabarito como conferencistas convidados: Clayton $\mathrm{H}$. Heathcock, Edmundo Ruveda, Edward Piers, Gerald Pattenden, Joseph P. Marino, Paul A. Wender, Peter A. Jacobi, Reinhardt W. Hoffmann e Renzo Rossi.

O número de participantes permaneceu estável em cerca de 200, estabelecendo-se a orientação de facilitar a participação de estudantes de graduação e pós-graduação, de modo a incentivar a interação dos mesmos com os pesquisadores brasileiros e estrangeiros, estimulando o intercâmbio de idéias e de estudantes, na tentativa de 
evitarmos a endogenia. Nesse encontro, a lingua inglesa foi estabelecida como idioma oficial e os encontros foram batizados de BMOS (Brazilian Meeting on Organic Synthesis). Outra prática recomendada foi que esses encontros deveriam ser itinerantes e realizados em locais com boa concentração de químicos orgânicos sintéticos.

Assim, em 1990, foi organizado o $4^{\text {th }}$ BMOS em Teresópolis tendo o prof. Vitor Ferreira como secretário geral. Em 1992 a Unicamp sediou o $5^{\text {th }}$ BMOS e, em 1994, a USP, São Paulo foi sede do $6^{\text {th }}$ BMOS, tendo como secretários gerais os profs. Ronaldo A. Pilli e João V. Comasseto, respectivamente. Em 1996, realizou-se no Rio de Janeiro o $7^{\text {th }}$ BMOS, com o prof. Joaquim F. Silva como secretário geral e o prof. Angelo Pinto como chairman, quando ficou decidida a realização do $8^{\text {th }}$ BMOS em 1998 em São Carlos, tendo novamente o prof. Tércio como secretário geral. Seu falecimento prematuro em 1997, levou a uma mudança de planos, transferindo-se o encontro para a estância de São Pedro, interior de São Paulo, tendo o prof. Luiz Carlos Dias da Unicamp como secretário geral.

Todos esses encontros contaram com um número considerável de participantes, particularmente o $5^{\text {th }}, 6^{\text {th }} \mathrm{e}$ $8^{\text {th }}$ BMOS que registraram mais de 300 inscritos. Isso ocorreu, certamente, pelo fato de esses três encontros haverem sido realizados em ou próximo de centros universitários com grande número de estudantes e pelas facilidades oferecidas pelos organizadores para a participação de estudantes locais e daqueles provenientes de outras cidades e estados.

Ao longo desses anos, grandes líderes, da química sintética internacional, além dos pioneiros já mencionados, prestigiaram os BMOS com sua presença: Andrew E. Greene, Armin de Meijere, Barry M. Trost, Bernd Giese, Bert Fraser-Reid, Cesare Gennari, David A. Evans, Dennis O. Curran, Dieter Seebach, Edward Piers, Ekkehard Winterfeldt, Erick M. Carreira, Gary A. Molander, Gerard Descotes, Gilbert Stork, Goverdhan Mehta, J. Bryan Jones, Ian Paterson, Jean D'Angelo, Jonathan A. Ellman, José Barluenga, Joseph P. Marino, Kenji Mori, Larry E. Overman, Leon Ghosez, Mark Lautens, Miguel E. Alonso, Minoru Isobe, Miwako Mori, Nigel S. Simpkins, Oreste A. Mascaretti, Paul Jenkins, Paul J. Reider, Pierre Laszlo,
Reinaldo S. Compagnone, Roberto F. de La Pradilla, Stephan Hanessian, Tohru Fukuyama, Tomas Hudlicky, Viresh Rawal e William R. Roush. A comunidade de químicos orgânicos brasileiros é grata a todos pela colaboração prestada.

O $9^{\text {th }}$ BMOS, que se realiza este ano na cidade de Curitiba tem o prof. Fábio Simonelli como secretário geral e um de nós (JVC) como chairman. É significativo ressaltar que o prof. Fabio participou, como estudante de iniciação científica do prof. Tercio, de nosso primeiro encontro de síntese no Instituto de Química da Universidade de São Paulo, em 1986, pois mostra que uma nova geração assumiu a incumbência de continuar o trabalho da geração anterior. Como não podia deixar de ser, o $9^{\text {th }}$ BMOS reúne uma plêiade de cientistas do mais alto gabarito e, tão importante quanto, um grande número de jovens químicos orgânicos sintéticos que se dedicam aos mais diversos ramos da síntese orgânica, muitos deles tendo realizado estudos de doutorado ou pós-doutorado nos laboratórios dos conferencistas das edições anteriores do BMOS.

Considerável progresso foi alcançado ao longo desses últimos 20 anos em que vários de nós acalentaram o sonho de ter no país uma comunidade de químicos orgânicos sintéticos atuante e competitiva: vários grupos estão consolidados, publicam regularmente em revistas nacionais e internacionais e tem o reconhecimento de seus pares do Brasil e do exterior.

Esses fatos nos dão a reconfortante sensação que a geração que deu início a esses eventos fez um bom trabalho e que aquelas que a sucedem continuarão consolidando a comunidade científica de nosso país com o mesmo ou maior entusiasmo. Mas certamente ainda há muito por fazer. Temos que continuar contribuindo para a nossa área de pesquisa com idéias inovadoras e desafiadoras, treinando adequadamente nossos estudantes e preparando as novas gerações para que venham a contribuir para o avanço do conhecimento científico em seu sentido mais amplo.

João V. Comasseto Ronaldo A. Pilli Fabio Simonelli 
Editorial

\section{The Brazilian Meetings on Organic Synthesis (BMOS). A Retrospective}

Organic synthesis in Brazil had a modest beginning in the fifties at the University of São Paulo, USP, with research carried out by prof. Marcelo de Moura Campos and Nicola Petragnani. At that time, these professors did pioneering work in the field of organic syntheses of selenium and tellurium compounds considered at that time a chemical curiosity, since no practical application was known for them. This was due to the simple fact that nothing was known about them!

Nowadays the chemistry of both elements have resulted in groundbreaking discoveries in the development of synthetic organic chemistry and several reactions discovered at that time at the Institute of Chemistry, USP, are classic examples in organic chemistry, presented in almost all textbooks of synthetic organic chemistry. As an example, we cite the selenocyclization of unsaturated substrates (M. Moura Campos, N. Petragnani, Chem. Ber. 1960, 93, 317). Unfortunately, the international community does not give credit for this discovery to these Brazilian scientists.

In the early seventies, with several large chemical industries being established in Brazil, the formation of chemists with a modern view of the field of organic synthesis was demanded. Help was sought by the National Council for Science and Technology (CNPq) at prof. Moura Campos's laboratory, establishing an agreement with the National Academy of Science (NAS) in the USA under the guidance of prof. Carl Djerassi. This program brought to Brazil some outstanding American scientists of that time, among them H. Taube, W. S. Johnson, R. E. Ireland and J. Marshall, as well as some of their former $\mathrm{PhD}$ and postdoctoral students to introduce new lines of research. The agreement in the field of organic synthesis, coordinated originally by prof. Moura Campos and, after his retirement, by prof. Nicola Petragnani was successful and we can state that it was, among the several agreements established at that time between CNPq and NAS, the most successful one, producing a considerable number of $\mathrm{MSc}$ and $\mathrm{PhD}$ students, among which were those who initiated the Brazilian Meetings on Organic Synthesis (BMOS).

Also during the 70's, the University of Brasilia (UnB) and the State University of Campinas (Unicamp) hired brazilian and foreign organic chemists educated in the USA. In the eighties, Unicamp continued to invest in the field and at the Federal University of Rio de Janeiro (UFRJ) and the Federal University of Minas Gerais (UFMG), several natural products chemists started to dedicate themselves to organic synthesis. By the end of the seventies and early eighties, research groups formed mainly by former PhD students of the Institute of Chemistry, USPSão Paulo, and dedicated to organic synthesis, had established themselves at the campus of University of São Paulo located in Ribeirão Preto and at the Federal University of São Carlos (UFSCar).

In the second half of the eighties all the laboratories mentioned above started to form researchers in the field of organic synthesis who are actively working in companies and Universities in several regions of Brazil.

The first attempt to get Brazilian synthetic organic chemists together took place at the University of Brasília in 1982 as an initiative of prof. Peter Bakuzis, when about 15 organic chemists met to discuss their research projects.

In 1986, one of us (JVC) organized an informal meeting at the Institute of Chemistry, USP that attracted around 100 participants among senior and junior researchers, as well as graduate and undergraduate students, all having organic synthesis as their subject of research. At this meeting, the basis of a periodical meeting of the organic chemists dedicated to organic synthesis in Brazil was established, it being agreed that the next meeting would be in Porto Alegre, under the coordination of prof. Valter Stefani, with the support of one of us (JVC).

This meeting was successfully carried out in 1987, with around 200 participants. In Porto Alegre, it was agreed that the following meeting would take place in São Carlos in 1988, and that prof. José Tércio B. Ferreira would act as the general secretary.

The $3^{\text {rd }}$ BMOS changed the scope of our meetings as nine outstanding international synthetic organic chemists were invited as guest lecturers (Clayton H. Heathcock, Edmundo Ruveda, Edward Piers, G. Pattenden, Joseph P. Marino, Paul A. Wender, Peter A. Jacobi, R. W. Hoffman and Renzo Rossi), English was the official language and international advertisement was sought.

It was clear in the minds of those who helped prof. Tercio to organize the first BMOS with invited foreign speakers that one of the major goals should be to foster the active participation of graduate and undergraduate students with research interests in organic synthesis. In fact, several sandwich and pos-doctoral programs involving brazilian PhD students were established as a result of this initiative. 
Another practice recommended was that the following meetings would take place in different locations, always involving considerable number of synthetic organic chemists.

In fact, the $4^{\text {th }}$ BMOS took place in Teresópolis, RJ in 1990 having Professor Vitor F. Ferreira as general secretary. In 1992, Unicamp hosted the $5^{\text {th }}$ BMOS and in 1994 the $6^{\text {th }}$ BMOS was organized at USP, São Paulo, under the responsabilities of prof. Ronaldo A. Pilli and João V. Comasseto, respectively.

In 1996, the $7^{\text {th }}$ BMOS took place in Rio de Janeiro with prof. Joaquim F. Silva as the general secretary and Angelo C. Pinto as the chairman, when it was decided that the $8^{\text {th }}$ BMOS to be held in 1998 would return to São Carlos and that prof. Tércio would once more act as the general secretary. His premature death in 1997 led to a change of plans and the $8^{\text {th }}$ BMOS was transfered to the countryside of São Paulo State (São Pedro) having prof. Luiz Carlos Dias of Unicamp as the general secretary.

All these meetings had a significant number of participants, particularly the $5^{\text {th }}, 6^{\text {th }}$ and $8^{\text {th }}$ BMOS which had more than 300 registrations. That was certainly due to the fact that these meetings were held in places which attracted a large number of students, due to the facilities offered by the organizers for both local students and also those from other cities and states. We firmly believe that all action should be taken to assure massive participation of students in these events.

Throughout the years, many outstanding international synthetic chemists, besides the pioneers already mentioned, gave us the honor to participate in the BMOS: Andrew E. Greene, Armin de Meijere, Barry M. Trost, Bernd Giese, Bert Fraser-Reid, Cesare Gennari, David A. Evans, Dennis O. Curran, Dieter Seebach, Ekkehard Winterfeldt, Erick M. Carreira, Gary A. Molander, Gerard Descotes, Gilbert Stork, Goverdhan Mehta, J. Bryan Jones, Ian Paterson, Jean D’Angelo, Jonathan A. Ellman, José Barluenga, Kenji Mori, Larry E. Overman, Leon Ghosez, Mark Lautens, Miguel E. Alonso, Minoru Isobe, Miwako Mori, Nigel S. Simpkins, Oreste A. Mascaretti, Paul Jenkins, Paul J.
Reider, Pierre Laszlo, Reinaldo S. Compagnone, Roberto F. de La Pradilla, Stephan Hanessian, Tohru Fukuyama, Tomas Hudlicky, Viresh Rawal and William R. Roush. We are grateful to all of them for their contribution to the success of our meetings!

The $9^{\text {th }}$ BMOS is scheduled to take place in Curitiba in 2001 and prof. Fábio Simonelli is in charge of its organization while one of us (JVC) was indicated as the chairman. It is significant to point out that prof. Simonelli participated, as an undergraduate student from prof. Tércio's laboratory, in the meeting organized at Institute of Chemistry, USP, in 1986. This is a highly meaningful fact, since it shows that a new generation took the responsibility to continue the work started by their predecessors. As usual, the $9^{\text {th }}$ BMOS gathers together a group of outstanding scientists, and not less important, a large number of young synthetic organic chemists that dedicate themselves to different branches of organic synthesis, many of them having obtained their $\mathrm{PhD}$ or done their post-doctoral studies under the supervision of previous BMOS lecturers.

We have certainly gone a long and successful way since some of us, about 20 years ago, cherished a dream: having a lively and competitive community established in Brazil devoted to synthetic organic chemistry, publishing regularly in international journals and pursuing inovative ideas. We are pleased to see that several brazilian organic chemists are respected in Brazil and abroad for their contributions to the field. But there is certainly much more to be done. We have to be able not only to contribute to our field of research with innovative and challenging ideas but also to prepare the new generations to come with a scientific knowledge as broad as possible in order to be able to take a step further and contribute to scientific knowledge in its broadest sense.
João V. Comasseto
Ronaldo Aloise Pilli
Fabio Simonelli 